\title{
Controlled Atmosphere Storage, Temperature Conditioning, and Antioxidant Treatment Alter Postharvest 'Honeycrisp' Metabolism
}

\author{
Rachel S. Leisso \\ Tree Fruit Research Laboratory, United States Department of Agriculture, \\ Agricultural Research Service, Wenatchee, WA
}

\section{Ines Hanrahan \\ Washington Tree Fruit Research Commission, Wenatchee, WA}

\author{
James P. Mattheis and David R. Rudell ${ }^{1}$ \\ Tree Fruit Research Laboratory, United States Department of Agriculture, \\ Agricultural Research Service, Wenatchee, WA
}

Additional index words. Malus $\times$ domestica Borkh., chilling injury, carbon dioxide injury, peel, cortex, soft scald, soggy breakdown, primary metabolism

\begin{abstract}
The physiology and metabolism characterizing postharvest chilling and $\mathrm{CO}_{2}$ injury in apple has important implications for postharvest management of soft scald and soggy breakdown. This research assessed differences of primary metabolism related to soggy breakdown (cortex $\mathrm{CI}$ ) and $\mathrm{CO}_{2}$ cortex injury in 'Honeycrisp' apple fruit. Results indicate that prestorage temperature conditioning, diphenylamine (DPA), and CA treatments alter fruit metabolism and affect peel and cortex storage disorder outcome. A preliminary summary of primary metabolism involved with soggy breakdown under high $\mathrm{CO}_{2}$ includes increased activity in glycolysis/gluconeogenesis, propionate metabolism, and alanine, aspartate, and glutamate metabolism.
\end{abstract}

CI of 'Honeycrisp' apple fruit is often manifested as either soft scald, which is characterized by sunken, ribbon-like brown regions of the peel (Barker, 1938; Snowdon, 1990), or soggy breakdown, a cortex disorder characterized by similarly demarcated regions of flesh tissue that can occur in the absence of soft scald (Plagge and Maney, 1928). Soft scald and soggy breakdown risk tends to be elevated as harvest maturity increases (Tong et al., 2003; Watkins et al., 2005). Soft scald and soggy breakdown can also occur simultaneously (Watkins et al., 2005).

Soggy breakdown has been attributed to CI (Plagge and Maney, 1928; Smock, 1977), but evidence of anaerobic metabolism (Leisso et al., 2015) suggests gas exchange or respiration rates may affect symptom development. Previous research also reveals increases in ethanol and fermentative odors concurrent with soggy breakdown development (Smock, 1977).

Internal $\mathrm{CO}_{2}$ injury of 'Honeycrisp' apple fruit has not been exhaustively studied, but it has been reported to be exacerbated by controlled atmosphere (CA) conditions with elevated $\mathrm{CO}_{2}(3 \mathrm{kPa})$ and reduced $\mathrm{O}_{2}$ $(0 \mathrm{kPa})\left(\right.$ Contreras et al., 2014). $\mathrm{CO}_{2}$ injury of apple fruit generally exhibits either of

Received for publication 14 Oct. 2016. Accepted for publication 23 Jan. 2017.

${ }^{1}$ Corresponding author. E-mail: david.rudell@ars. usda.gov. two types of symptoms: externally, as rugose, sunken, browned peel, or internally as browned cortex tissue that develops into open ovate pits with time; internal symptoms tend to be more severe toward the calyx end of the fruit (Smock, 1977). In one study, focusing specifically on internal $\mathrm{CO}_{2}$ injury, harvest maturity did not appear to affect disorder incidence (Contreras et al., 2014), unlike soft scald and soggy breakdown. However, both soft scald (Watkins et al., 2004) and $\mathrm{CO}_{2}$ injury (Contreras et al., 2014) can be reduced by conditioning apples at a higher temperature before longer term CA or cold storage. CA management is an important tool for increasing fruit longevity in storage, but the prevalence of physiological disorders perceived as internal $\mathrm{CO}_{2}$ injury complicates recommendations for specific CA regimes for 'Honeycrisp' apples (Beaudry and Contreras, 2010; Hanrahan and McFerson, 2010).

Prange and DeLong (2006) divided CA disorders into three categories: "1) disorders that occur in air storage that are alleviated by $\mathrm{CA}$; 2) disorders that occur in air storage that are aggravated by CA; and 3) disorders that are not known to occur or rarely occur in air storage and are induced by CA." It remains unclear whether soggy breakdown (internal cortex injury) is caused primarily by chilling or if elevated $\mathrm{CO}_{2}$ influences symptom development, possibly exacerbating gaseous diffusion resistance gradients within apples, which have been characterized in 'Kanzi', 'Jonagold', and 'Braeburn' (Ho et al., 2010). Symptoms similar to soggy breakdown (sharply demarcated regions of browned flesh) were exacerbated in high $\mathrm{CO}_{2}$ storage environments alongside typical $\mathrm{CO}_{2}$ injury symptoms (browned flesh tissue containing lens-shaped pits), confounding visual diagnosis (Contreras et al., 2014). Focusing on the metabolic profile associated with these disorders could lend insight into whether these disorders share a similar etiology or are metabolically distinct.

Postharvest disorders associated with elevated $\mathrm{CO}_{2}$ levels may also be distinguished from other disorders using the antioxidant DPA and elevated $\mathrm{CO}_{2}$ during CA storage. A DPA drench before storage reduces or eliminates internal (Argenta et al., 2002; de Castro et al., 2008; Felicetti et al., 2011; Meheriuk and Lau, 1984) and external $\mathrm{CO}_{2}$ injury during $\mathrm{CA}$ storage in a number of susceptible apple cultivars, although any further relationship with oxidative stress remains to be established (Fernández-Trujillo et al., 2001). DPA treatment reduced soft scald/soggy breakdown in one experiment, but was not consistent for controlling soft scald/soggy breakdown in 'Honeycrisp' (Watkins et al., 2004).

Metabolomics has been described as the apogee of the omics trifecta, among transcriptomics and proteomics (Patti et al., 2012) and, as the final step of many cell regulatory processes and the composition of any organism, a metabolic profile represents the ultimate construct of the phenotype (Fiehn, 2002). Metabolomic approaches are either targeted or untargeted, where targeted approaches assess metabolites of specific chemical classes or pathways [e.g., Zhang et al. (2010)], and untargeted approaches assess as many metabolites as possible through several complementary laboratory and instrumental combinations (Patti et al., 2012). Assessment of a metabolic profile for a fruit or subset of fruit begins with sample collection and cryostabilization, followed by metabolite extraction using multiple methods to estimate multiple classes of metabolites (Rudell and Mattheis, 2009; Rudell et al., 2009, 2011). Metabolic profiling has been used to characterize metabolism associated with apple fruit disorders and lends insight into the biological mechanisms underlying disorder development (Lee et al., 2012b; Rudell and Mattheis, 2009).

This experiment combined CA, temperature conditioning, and DPA treatments to provoke differential incidence of soft scald/soggy breakdown and $\mathrm{CO}_{2}$ injury. Our hypothesis was that symptoms and cortex metabolic profile would differ depending upon $\mathrm{CO}_{2}$ levels, DPA treatment, and temperature regardless of symptom appearance.

\section{Materials and Methods}

'Honeycrisp' apples were picked on 26 Sept. 2012 from a commercial orchard near Yakima, WA (lat. 46.57583, long. 
$-120.63855)$. This was the third commercial pick from this orchard. Fruit were immediately transported to Wenatchee, WA. At-harvest maturity was assessed as outlined previously including starch, Brix, titratable acidity, and internal ethylene concentration (IEC) (Leisso et al., 2015). External disorder and damage free fruit were selected from each bin and placed onto pressed paper trays (16 fruit per tray); a total of eight trays were assigned to each of seven treatments. Chemical and temperature treatments were initiated or applied the same day at listed in Table 1; CA treatments were initiated $24 \mathrm{~h}$ following harvest in automatically controlled chambers. Treatments are hereby referred to as T1-T7. Each treatment was ultimately stored in a separate small CA chamber, with the exception of $\mathrm{T} 7$, which was stored in two apple boxes on a small pallet in the same room as the CA chambers. Chamber dimensions and automated atmospheric controlled were as described by Mattheis et al. (1998). For T4, an emulsion containing DPA was made by dissolving $2 \mathrm{~g}$ of DPA (Sigma-Aldrich, St. Louis, MO) in a solution of $2.5 \mathrm{~mL}$ of isopropanol and $8 \mathrm{~mL}$ of Triton X-100 (Sigma-Aldrich), and then bringing the final volume to $1 \mathrm{~L}$ using $\mathrm{dH}_{2} \mathrm{O}$. Fruit were treated by immersion in the emulsion for $1 \mathrm{~min}$ and then air dried in an upright position (calyx end down) on the tray before storage. T5 was a "carrier" control for T4 containing $2.5 \mathrm{~mL}$ isopropanol and $8 \mathrm{~mL}$ of Triton X-100 diluted to a final volume of $1 \mathrm{~L}$. Fruit from T1 and T2 were temperature conditioned $\left(7 \mathrm{~d}\right.$ at $\left.10{ }^{\circ} \mathrm{C}\right)$ in a separate cold storage room and, then moved to heated chambers (to maintain $3{ }^{\circ} \mathrm{C}$ ) in the same room as the other $\mathrm{CA}$ chambers, which was maintained at $1{ }^{\circ} \mathrm{C}$.

External and internal disorder symptoms were evaluated weekly from 0 to 24 weeks storage on one tray per treatment. At 8 weeks, all trays were removed from the CA chambers and evaluated for incidence and severity of peel damage. Two trays (32 fruit) were retained for each treatment, and fruit weight was measured and cortex browning incidence and severity were rated (Table 2), while the remaining trays (four trays, 64 fruit) were returned to the CA chambers for subsequent disorder monitoring. Cortex from the two rated trays was then sampled for further metabolic analyses by dissecting healthy tissue (W) from browned tissue (B); wholly healthy fruit were also sampled $(\mathrm{H})$. Cortex tissue was primarily excised from a region $5 \mathrm{~mm}$ below the peel and above the core line. Fruit pieces were rapidly diced into small cubes $\left(\approx 10 \mathrm{~mm}^{3}\right)$, and flash frozen in liquid nitrogen. All evaluations and sampling were performed at $1{ }^{\circ} \mathrm{C}$. Cortex from all treatment (T1-T7)/tissue $(\mathrm{H}, \mathrm{W}$, and $\mathrm{B})$ combinations were replicated three times with each replicate containing tissue from three different fruit, with the exception of $\mathrm{T} 1$, where only one biological replication was possible for $\mathrm{W}$ and $\mathrm{B}$ tissue due to low injury incidence.

Volatile metabolites and organic acids, carbohydrates, phenolics, and amino acids were assessed for tissue collected at 8 weeks of storage, using extraction methods and GC-MS instrumentation as previously described (Lee et al., 2012a; Rudell et al., 2011). Each biological replication was assessed individually, with the exception of T1 (tissues W and B) where the sole biological sample (containing pieces of three fruit) was assessed in three separate technical replications.

GC-MS data were collected and assessed using ChemStation (Agilent Technologies Inc., Santa Clara, CA) and the deconvolution reporting service (DRS) program for volatile metabolites, organic acids, carbohydrates, phenolics, and amino acids (Table 3 ) as well as other metabolites characterized only by mass spectral tags (principal ions and Kovat's index). A Kyoto Encyclopedia of Genes and Genomes (KEGG) number was also assigned to each metabolite for use in pathway analysis via Metabolomic Pathway Analysis (MetPA) (Xia et al., 2012; Xia et al., 2009). For subsequent statistical analyses, data were normalized by, first, mean centering and, then, dividing by the square root of the standard deviation of each variable.

Principal components analyses (PCA), a type of unsupervised multivariate modeling, were carried out on metabolite data using Unscrambler version 10.2 (Camo Software Inc., Woodbridge, NJ). For this multivariate modeling method, an algorithm (NIPALS) partitions the variance among samples in an iterative fashion, such that the first factor explains the most of the sample variance, the second slightly less. The number of factors required to explain the greater portion of the variance can be indication of the complexity of the data. As an unsupervised type of multivariate modeling, PCA enables discernment of latent trends in the metabolite data without specifically assessing the effects of a particular treatment.

Analysis of variance (ANOVA) followed by post hoc Fisher's least significant difference (LSD) was used to assess the significant difference of individual metabolite levels among treatments or tissue. In addition, MetPA (Xia et al., 2012) was used to identify specific biochemical pathways that were altered by treatments. MetPA uses KEGG database (Kanehisa and Goto, 2000) for metabolic pathway information on model organisms. Arabidopsis thaliana was used for pathway mapping. On the basis of the subset of identified metabolites annotated in KEGG, injury affected pathways were found using the "global test" in pathway enrichment analysis and "relative-betweenness centrality" for pathway topology analysis.

\section{Results and Discussion}

Values for harvest maturity indices were as follows: starch index $(1-6)=5.7 \pm 0.072(\mathrm{SE})$, soluble solids $=12.9 \pm 0.10^{\circ} \mathrm{Brix}$, titratable

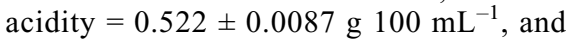
internal ethylene concentration $($ IEC) $=$ $0.78 \pm 0.072 \mu \mathrm{L} \cdot \mathrm{L}^{-1}$. The starch index indicates fruit were climacteric although the IEC indicates otherwise. Susceptibility to soggy breakdown typically increases with harvest maturity (Tong et al., 2003).

Fruit treated using temperature conditioning (T1 and T2) had the lowest peel and cortex disorder incidence (Table 2). The number of fruit affected by internal browning disorders under the same temperature conditioning regime was significantly higher in T2 (high $\mathrm{CO}_{2}$ ) than $\mathrm{T} 1$ (lower $\mathrm{CO}_{2}$ ), suggesting atmospheric conditions impacted disorder development. Temperature conditioning has repeatedly proved an effective means for reducing soft scald/soggy breakdown incidence (DeLong et al., 2004, 2006; Watkins et al., 2004) and $\mathrm{CO}_{2}$ injury (Contreras et al., 2014). DPA treatment (T4) reduced total disorder incidence relative to other fruit stored under similar high $\mathrm{CO}_{2} \mathrm{CA}(5 \mathrm{kPa}$ $\left.\mathrm{CO}_{2}\right)$ and low-temperature $\left({ }^{\circ} \mathrm{C}\right)$ conditions (T5 and T6), although less than temperature conditioning. Remaining treatments all had similar high incidence of peel and cortex injury to T5 and T6 (Table 2) indicating that

Table 1. Postharvest 'Honeycrisp' treatments (storage and crop protectant regimes), Fall 2012-13. Treatments were assigned to assess the impact of storage temperature, storage atmosphere, and diphenylamine on fruit cortex disorder incidence and metabolism.

\begin{tabular}{|c|c|c|c|c|}
\hline $\begin{array}{l}\text { Treatment } \\
\text { number }\end{array}$ & $\begin{array}{l}\text { Conditioning } \\
\text { temp. }(7 \mathrm{~d})\end{array}$ & $\begin{array}{l}\text { Final temp. } \\
\left({ }^{\circ} \mathrm{C} /{ }^{\circ} \mathrm{F}\right)\end{array}$ & Atmosphere treatment & Expected treatment outcome \\
\hline $\mathrm{T} 2$ & $10^{\circ} \mathrm{C}\left(50^{\circ} \mathrm{F}\right)$ & $3{ }^{\circ} \mathrm{C}\left(37.5^{\circ} \mathrm{F}\right)$ & High $\mathrm{CO}_{2}\left(5 \mathrm{kPa} \mathrm{CO}, 2 \mathrm{kPa} \mathrm{O}_{2}\right)$ & No soft scald/soggy breakdown, but possibly $\mathrm{CO}_{2}$ injury \\
\hline $\mathrm{T} 3$ & & $1^{\circ} \mathrm{C}\left(33^{\circ} \mathrm{F}\right)$ & $\mathrm{CA}\left(1 \mathrm{kPaCO} \mathrm{CO}_{2}, 2 \mathrm{kPa} \mathrm{O}\right)$ & Soft scald/soggy breakdown, no $\mathrm{CO}_{2}$ injury \\
\hline T5 & & $1{ }^{\circ} \mathrm{C}\left(33^{\circ} \mathrm{F}\right)$ & $\begin{array}{l}\text { High } \mathrm{CO}_{2}\left(5 \mathrm{kPa} \mathrm{CO} \mathrm{CO}_{2}, 2 \mathrm{kPa} \mathrm{O} 2\right) \\
\quad+\text { IPA/Triton control }\end{array}$ & $\begin{array}{l}\text { A control for the DPA (soft scald/soggy breakdown and } \mathrm{CO}_{2} \\
\text { injury possible) }\end{array}$ \\
\hline
\end{tabular}


Table 2. Fruit quality assessment of 'Honeycrisp' apples following 8 weeks storage under different storage and crop protectant regimes. Percentages are given of fruit impacted by one or more variables (columns 2 and 4) as well as percentage of total tissue impacted (columns 3 and 5). Lower case letters indicate significant differences within each variable as determined using pairwise chi-square tests for incidence comparison or analysis of variance followed by Fisher's least significant difference post hoc test for total area and volume comparison.

\begin{tabular}{|c|c|c|c|c|c|c|c|c|}
\hline Number & $\begin{array}{l}\text { Preconditioning } \\
(7 \mathrm{~d})\end{array}$ & Storage temp & $\begin{array}{l}\text { Atmospheric } \\
\text { conditions }\end{array}$ & $\begin{array}{c}\% \text { fruit affected } \\
\text { by peel } \\
\text { browning } \\
(\mathrm{n}=96)\end{array}$ & $\begin{array}{l}\% \text { peel area } \\
\text { affected } \\
\text { by browning }\end{array}$ & $\begin{array}{l}\% \text { fruit affected } \\
\text { by cortex browning } \\
(\mathrm{n}=32)\end{array}$ & $\begin{array}{c}\% \text { volume } \\
\text { affected by } \\
\text { cortex browning }\end{array}$ & $\begin{array}{l}\text { Fruit wt }(\mathrm{g}) \\
\quad(\mathrm{n}=32)\end{array}$ \\
\hline$\overline{\mathrm{T} 1}$ & $10^{\circ} \mathrm{C}\left(50^{\circ} \mathrm{F}\right)$ & $3^{\circ} \mathrm{C}\left(37.5^{\circ} \mathrm{F}\right)$ & $\begin{array}{l}\text { Normal CA }(1 \mathrm{kPa} \mathrm{CO} \text {, } \\
\left.\quad 2 \mathrm{kPa} \mathrm{O}_{2}\right)\end{array}$ & $3 \mathrm{~b}$ & $0.6 \mathrm{~b}$ & $9 \mathrm{~d}$ & $0.7 \mathrm{~b}$ & 197.1 \\
\hline $\mathrm{T} 2$ & $10^{\circ} \mathrm{C}\left(50^{\circ} \mathrm{F}\right)$ & $3^{\circ} \mathrm{C}\left(37.5^{\circ} \mathrm{F}\right)$ & $\begin{array}{l}\text { High } \mathrm{CO}_{2}\left(5 \mathrm{kPa} \mathrm{CO}_{2},\right. \\
\left.\quad 2 \mathrm{kPa} \mathrm{O})_{2}\right)\end{array}$ & $16 \mathrm{~b}$ & $0.9 \mathrm{~b}$ & $25 \mathrm{c}$ & $6.1 \mathrm{~b}$ & 193.6 \\
\hline T3 & & $1^{\circ} \mathrm{C}\left(33^{\circ} \mathrm{F}\right)$ & $\begin{array}{l}\text { Normal CA }(1 \mathrm{kPa} \mathrm{CO} \text {, } \\
\qquad 2 \mathrm{kPa} \mathrm{O})_{2}\end{array}$ & $90 \mathrm{a}$ & $53.0 \mathrm{a}$ & $88 \mathrm{a}$ & $56.6 \mathrm{a}$ & 204.7 \\
\hline $\mathrm{T} 4$ & & $1^{\circ} \mathrm{C}\left(33^{\circ} \mathrm{F}\right)$ & $\begin{array}{c}\text { High } \mathrm{CO}_{2}\left(5 \mathrm{kPaCO} \mathrm{CO}_{2},\right. \\
\left.2 \mathrm{kPa} \mathrm{O}_{2}\right)+\mathrm{DPA}\end{array}$ & $59 \mathrm{a}$ & $10.1 \mathrm{~b}$ & $47 \mathrm{~b}$ & $7.0 \mathrm{~b}$ & 203.1 \\
\hline T5 & & $1^{\circ} \mathrm{C}\left(33^{\circ} \mathrm{F}\right)$ & $\begin{array}{l}\text { High } \mathrm{CO}_{2}(5 \mathrm{kPa} \mathrm{CO}, \\
\left.\quad 2 \mathrm{kPa} \mathrm{O}_{2}\right)+ \text { isopropanol }\end{array}$ & $88 \mathrm{a}$ & $57.2 \mathrm{a}$ & $88 \mathrm{a}$ & $68.6 \mathrm{a}$ & 218.2 \\
\hline T6 & & $1^{\circ} \mathrm{C}\left(33^{\circ} \mathrm{F}\right)$ & $\begin{array}{l}\text { High } \mathrm{CO}_{2}(5 \mathrm{kPa} \mathrm{CO} \text {, } \\
\left.\quad 2 \mathrm{kPa} \mathrm{O}_{2}\right)\end{array}$ & $79 \mathrm{a}$ & $52.0 \mathrm{a}$ & $88 \mathrm{a}$ & $68.4 \mathrm{a}$ & 199.5 \\
\hline \multirow[t]{2}{*}{$\mathrm{T} 7$} & & $1^{\circ} \mathrm{C}\left(33^{\circ} \mathrm{F}\right)$ & $\begin{array}{l}\text { Open air in } \mathrm{CA} \\
\text { chamber room }\end{array}$ & $85 \mathrm{a}$ & $55.0 \mathrm{a}$ & $84 \mathrm{a}$ & $51.6 \mathrm{a}$ & 201.1 \\
\hline & & & & $\mathrm{z}$ & $\mathrm{y} * * * *$ & $\mathrm{z}$ & $\mathrm{y} * * * *$ & NS \\
\hline
\end{tabular}

${ }^{\mathrm{z}}$ Pairwise chi-square tests where $P<0.05$.

${ }^{\mathrm{y}}$ Type III sums of squares.

Ns, ${ }^{*},{ }^{* * *}$ Nonsignificant or significant at $P<0.05,0.01$, or 0.001 , respectively.

Table 3. Metabolites detected in 'Honeycrisp' apple cortex tissue collected following 8 weeks of different postharvest storage and crop protectant regimes. Kyoto Encyclopedia of Genes and Genomes (KEGG) numbers were assigned to identify metabolites to enable pathway analysis.

\begin{tabular}{|c|c|c|c|}
\hline Metabolite & KEGG number & Metabolite & KEGG number \\
\hline$\overline{(E) \text {-2-hexenal }}$ & $\mathrm{C} 08497$ & Galactose & $\mathrm{C} 00124$ \\
\hline$(E, E)-2,4$-hexadienal & C19249 & Galacturonic acid & $\mathrm{C} 08348$ \\
\hline (Z)-3-hexen-1-ol & C08492 & Glucose & $\mathrm{C} 00031$ \\
\hline$(Z, E)$ a-farnesene & $\mathrm{C} 09665$ & Glucose-6-phosphate & $\mathrm{C} 00668$ \\
\hline 1-butanol & $\mathrm{C} 06142$ & Glucuronic acid & $\mathrm{C} 00191$ \\
\hline 1-pentanol & C16834 & Glycerol & $\mathrm{C} 00116$ \\
\hline 1-propanol & C05979 & Hexanoic acid & $\mathrm{C} 01585$ \\
\hline 2,3-butanediol & $\mathrm{C} 03044$ & Homoserine & $\mathrm{C} 00263$ \\
\hline 2-ethyl-1-hexanol & $\mathrm{C} 02498$ & Inositol & $\mathrm{C} 00137$ \\
\hline 2-methyl-1-propanol & C14710 & Isoleucine & $\mathrm{C} 00407$ \\
\hline 2-methylbutanal & $\mathrm{C} 02223$ & Leucine & $\mathrm{C} 00123$ \\
\hline 2-propanol & $\mathrm{C} 01845$ & Linalool & C11388 \\
\hline 5-oxo-proline & C01879 & Maleic acid & $\mathrm{C} 01384$ \\
\hline 6-methyl-5-hepten-2-ol & C07288 & Malic acid & C00149 \\
\hline 6-methyl-5-hepten-2-one & $\mathrm{C} 07287$ & Malonic acid & $\mathrm{C} 00383$ \\
\hline Acetaldehyde & $\mathrm{C} 00084$ & Methionine & $\mathrm{C} 00073$ \\
\hline Acetic acid & $\mathrm{C} 00033$ & Methyl 2-methylbutyrate & C18319 \\
\hline Acetone & $\mathrm{C} 00207$ & Methyl acetate & $\mathrm{C} 17530$ \\
\hline Alanine & $\mathrm{C} 00041$ & Methyl alcohol & $\mathrm{C} 00132$ \\
\hline Arginine & $\mathrm{C} 00062$ & Norvaline & $\mathrm{C} 01826$ \\
\hline Ascorbic acid & $\mathrm{C} 00072$ & Octanal & $\mathrm{C} 01545$ \\
\hline Asparagine & $\mathrm{C} 00152$ & Pentanal & C07329 \\
\hline Aspartic acid & C00049 & Phenylalanine & $\mathrm{C} 00079$ \\
\hline Benzaldehyde & $\mathrm{C} 00261$ & Phosphoric acid & $\mathrm{C} 00009$ \\
\hline Benzyl alcohol & $\mathrm{C} 00556$ & Pipecolic acid & $\mathrm{C} 00408$ \\
\hline$\beta$-farnesene & C09666 & Proline & $\mathrm{C} 00148$ \\
\hline Butanal & $\mathrm{C} 01412$ & Propanal & C00479 \\
\hline Butyl acetate & C12304 & Pyruvic acid & $\mathrm{C} 00022$ \\
\hline Citric acid & $\mathrm{C} 00158$ & Quinic acid & $\mathrm{C} 06746$ \\
\hline Cysteine & $\mathrm{C} 00736$ & Raffinose & $\mathrm{C} 00492$ \\
\hline Decanal & C12307 & Rhamnose & $\mathrm{C} 00507$ \\
\hline Erythrose & $\mathrm{C} 00279$ & S-adenosylmethionine & C00019 \\
\hline Estragole & C10452 & Salicylic acid & $\mathrm{C} 00805$ \\
\hline Ethanol & C00469 & Serine & $\mathrm{C} 00065$ \\
\hline Ethyl 2,4-decadienoate & $\mathrm{C} 08486$ & Shikimic acid & C00493 \\
\hline Ethyl Acetate & C00849 & Sorbitol & $\mathrm{C} 00794$ \\
\hline Ethylbenzene & $\mathrm{C} 07111$ & Succinic acid & $\mathrm{C} 00042$ \\
\hline Fructose & $\mathrm{C} 00095$ & Sucrose & C00089 \\
\hline Fructose 6-phosphate & $\mathrm{C} 00085$ & Threonine & C00188 \\
\hline Fumaric acid & $\mathrm{C} 00122$ & Tryptophan & $\mathrm{C} 00078$ \\
\hline Galactose & $\mathrm{C} 00124$ & Valine & $\mathrm{C} 00183$ \\
\hline Galacturonic acid & $\mathrm{C} 08348$ & & \\
\hline Glucose & $\mathrm{C} 00031$ & & \\
\hline Glucose-6-phosphate & $\mathrm{C} 00668$ & & \\
\hline Glucuronic acid & C00191 & & \\
\hline
\end{tabular}

it could be either soft scald/soggy breakdown or $\mathrm{CO}_{2}$ injury that was reduced by DPA treatment. Our visual and metabolic examination sought to confirm whether the injury reduced using DPA treatment is actually $\mathrm{CO}_{2}$ injury as previously reported (Contreras et al., 2014) or soft scald/soggy breakdown of 'Jonathan' (Wills et al., 1981; Wills and Scott, 1982).

Cortex and peel browning symptoms varied among treatments (Fig. 1). Fruit affected by internal and external browning from $\mathrm{T} 1$ (temperature conditioning, stored at $3{ }^{\circ} \mathrm{C}+1 \mathrm{kPa} \mathrm{CO}_{2}+2 \mathrm{kPa} \mathrm{O}_{2}$ ) exhibited sharply demarcated peel lesions, and also sharply demarcated brown regions in the cortex. Temperature conditioned + high $\mathrm{CO}_{2}$ fruit (T2) exhibited symptoms most similar to Smock's description of internal $\mathrm{CO}_{2}$ damage (1977), with extensive regions of browned cortex tissue toward the calyx end of the fruit (Fig. 1, T2-b). Only a small amount of damage was detected on the fruit surface (Fig. 1, T2-a), as may be expected on fruit with internal $\mathrm{CO}_{2}$ injury. Fruit stored in low-temperature $\mathrm{CA}$ with no conditioning (T3) mostly had symptoms typical of soft scald, with ribbon-like regions of browned peel corresponding to damaged cortex (Fig. 1, T3) and no indication of the characteristic radial browning toward the calyx end typical of $\mathrm{CO}_{2}$ injury. However, disorder incidence and severity in this treatment were relatively high. At 8 weeks, it was difficult to distinguish symptoms since so much of the cortex had already browned, although, at 4 weeks, symptoms were more typical to soft scald (not shown).

Despite the application of DPA, fruit stored at low temperature in $\mathrm{CA}+$ high $\mathrm{CO}_{2}$ (T4) to induce $\mathrm{CO}_{2}$ injury (Contreras et al., 2014) and soft scald (Wills et al., 1981) developed symptoms that included ribbon lesions typical to soft scald (Fig. 1, T4-a). 
$\mathrm{T} 1$

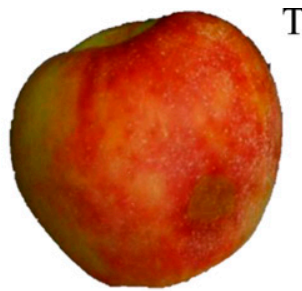

T3-a

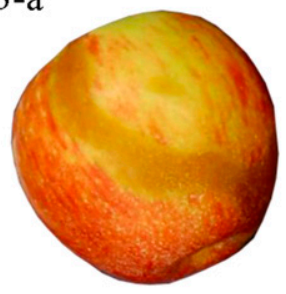

T4-b

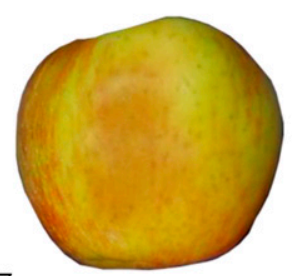

$\mathrm{T} 7$

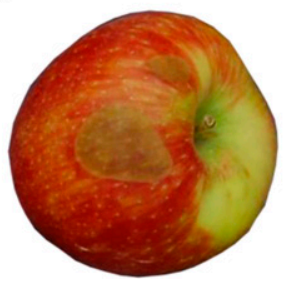

$\mathrm{T} 2-\mathrm{a}$

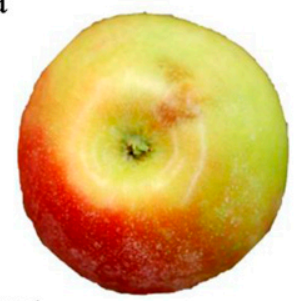

T3-b

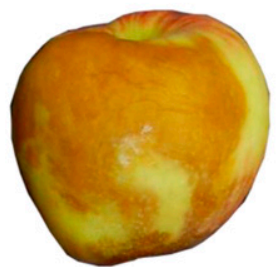

T5/6-a

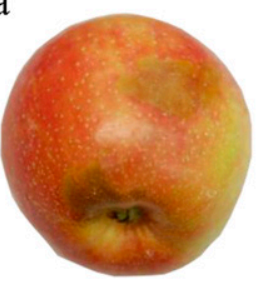

$\mathrm{T} 2-\mathrm{b}$

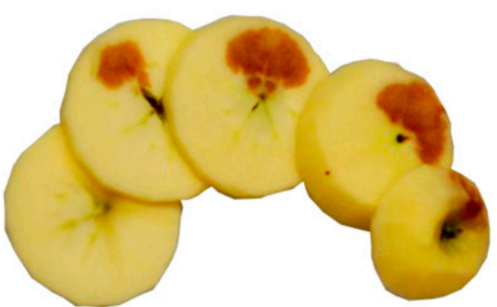

T4-a
$\mathrm{T} 5 / 6-\mathrm{b}$
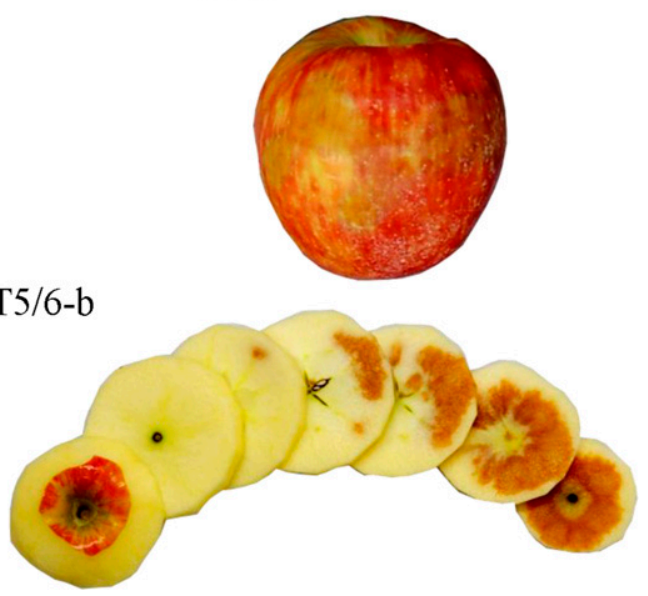

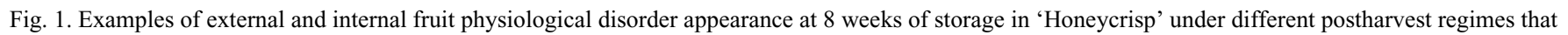
differentially impact external and internal disorder incidence and development (see Table 1 for treatment code). Letters indicate different exhibits of internal and/or external disorders.

However, disorder onset was delayed relative to other treatments, and no symptoms were apparent in this treatment at 4 weeks (data not shown). Although symptoms appeared similar to soft scald, one of 32 fruit sampled had internal damage confined to the calyx end, which is more similar to that attributed to $\mathrm{CO}_{2}$ injury. Also, two fruit from this treatment had symptoms of soft scald only confined to the peel. Overall, this treatment had lower severity of internal damage relative to peel injury compared with other treatments stored at $1{ }^{\circ} \mathrm{C}$ that were not conditioned before storage (Table 2).

Similarly, cortex browning symptom descriptions, where DPA was not used alongside $\mathrm{CA}+$ high $\mathrm{CO}_{2}$ (T5 and T6), were mixed, with peel lesions similar to soft scald, as well as internal browning confined to the calyx end of the fruit (Fig. 1, T5/6 a, b). Later in storage (24 weeks), cortex tissue from several treatments T2, T5, and T6 developed lens shaped pits more typical of $\mathrm{CO}_{2}$ injury, which was not found in cortex from other treatments, including DPA + CA + high $\mathrm{CO}_{2}$ (T4). Symptoms of browning in T7 were more typical to soft scald (Fig. 1, T7). Lens shaped pits have also been reported previously in 'Honeycrisp' cortex stored under conditions conducive to $\mathrm{CO}_{2}$ injury (Chiu et al., 2015; Contreras et al., 2014).

To summarize symptom presence/etiology with relation to treatments, disorder incidence was lowest in fruit treated with temperature conditioning and stored at higher temperature in $\mathrm{CA}\left(1 \mathrm{kPa} \mathrm{CO}, 2 \mathrm{kPa} \mathrm{O}_{2}\right)$, but since fruit were also under $\mathrm{CA}$ it is not possible to rule out the impact of low $\mathrm{O}_{2}$ on disorder development. Results suggested DPA may more effectively reduce $\mathrm{CO}_{2}$ injury symptoms than CI (soggy breakdown symptoms). DPA treatment has been purportedly effective for control of soft scald/soggy breakdown in other cultivars (cv. Jonathan) (Wills et al., 1981; Wills and Scott, 1982), although results are variable for 'Honeycrisp' (Watkins et al., 2004). This may indicate either that DPA can reduce these disorders in some cases or that $\mathrm{CO}_{2}$ injury may have common causes with respect to oxidative stress.

Overall differences of metabolism among treatments/tissue type (tissue health) combinations were, first, evaluated using PCA to model metabolic data (Fig. 2A). Also, metabolic differences among treatments within a single tissue type $(\mathrm{H}, \mathrm{W}$, or $\mathrm{B})$ were analyzed separately (Fig. 2B). The variation accounted for in the first two principal components was under $20 \%$ in every case indicating that much of the variability could not be structured and is inherent to further dimensions. In multivariate modeling, the proximity of one sample to another reflects the similarities in patterns of the underlying metabolic trends. All replications of every treatment/tissue combination were included in the analysis represented by three biological replications, although low soggy breakdown incidence only allowed enough tissue from T1-W and T1-B for technical replication rather than eliminating those treatment/tissue combinations from the metabolic analysis. Replications of these combinations, as may be expected, had more similar PCA scores than the biological replications of the other combinations.

To reduce the variance in the overall model and, consequently clarify associations among treatments as they are reflected in each treatment, samples from each tissue type $(\mathrm{H}, \mathrm{W}$, and $\mathrm{B})$ were analyzed using 

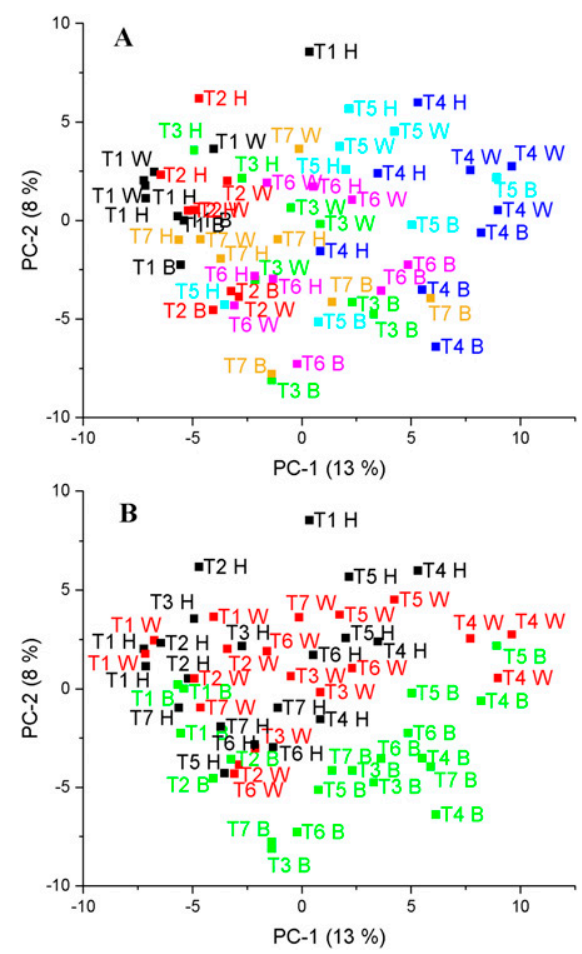

Fig. 2. Principal components analysis (PCA) scores plots of metabolic profiles from 'Honeycrisp' apple cortex. (A) Scores represent overall differences in the metabolic profile among different postharvest and storage regimes (treatments) and (B) tissue condition related to browning. Sample name and color indicates treatments in plot A (T1 = black, T2 = red, T3= green, T4 = blue, T5 = cyan, T6 = magenta, T7 = ochre); sample name and color indicates sample tissue $[\mathrm{H}($ black $)=$ wholly healthy fruit, $\mathrm{W}$ (cyan) $=$ healthy tissue in fruit affected by disorders, B (green) $=$ browned tissue in fruit affected by disorders]

separate PCA models. The variation accounted for in the first two principal components was under $30 \%$ in every case indicating that model did not explain the greater portion of the variance. However, this visualization of the scores plots revealed that differences among the treatment metabolomes are most apparent in browned symptomatic tissue $(\mathrm{H}$; Fig. 3A) followed by the asymptomatic tissue in soggy breakdown affected fruit (W; Fig. 3B) and, finally, cortex from entirely healthy fruit (B; Fig. 3C).

In the comparison of the metabolic profiles of fruit that remained entirely disorderfree $(H)$, treatments expected to have greater acclimation and less chilling stress (T1 and $\mathrm{T} 2$ ) or lower $\mathrm{CO}_{2}$ levels (T2, T3, and T7) exhibited the most divergence from DPA (T4) and high $\mathrm{CO}_{2}+$ low-temperature storage (T4, T5, and T6) (Fig. 3A). This supports the previous model indicating, in cortex tissue, DPA has a profound impact on fruit metabolism, which has also been demonstrated in other studies (Mattheis and Rudell, 2008). Similarities among T4, T5, and $\mathrm{T} 6$ most likely represent the response of healthy fruit to the imposed postharvest conditions, some of which may be related to fruit adaptation to the low temperature/high $\mathrm{CO}_{2}$ environment.

Scores of cortex metabolomes from asymptomatic tissue adjacent to symptomatic tissue (W) were somewhat similar to the scores of $\mathrm{H}$ cortex in this model with respect to their relationship on PC1 (Fig. 3B). $\mathrm{CA}+$ High $\mathrm{CO}_{2}$ (T6) scores for two replications (T6-W) were more closely related with those of treatments using temperature conditioning and higher storage temperatures (T1 and T2) or low $\mathrm{CO}_{2}$ (T3). T6 was unlike T5 $\left(\mathrm{CA}+\right.$ high $\mathrm{CO}_{2}+$ isopropyl alcohol/Triton $\mathrm{X}-100$ ) suggesting the inactive ingredients in the DPA formulation may have impacted metabolism in this tissue. As with $\mathrm{H}$ tissue, T4 and $\mathrm{T} 5$ had similar distribution in PCA scores plots, indicating similar metabolism provoked by high $\mathrm{CO}_{2}$ and colder storage temperature leading to adaptation rather than the symptom development that occurred in adjacent tissue. Replications of air stored fruit (T7) were inconsistent, but divergent from all other treatments, indicating regular air storage affects fruit metabolism with respect to disorder onset. Metabolic composition was not clearly delineated on the basis of merely high $\mathrm{CO}_{2} \mathrm{CA}$ (T2, T4, T5, and T6) nor low temperature (T3, T4, $\mathrm{T} 5, \mathrm{~T} 6$, and T7) in the first two principal components.

In browned symptomatic tissue (B), treatments expected to have underwent less chilling stress ( $\mathrm{T} 1$ and $\mathrm{T} 2$ ), were closely grouped indicating a key effector of the metabolomes of symptomatic tissue is storage temperature (Fig. 3C). As B tissue has already developed symptoms, these differences may be less related to metabolic adaptation than merely a reflection of metabolism associated with temperature.

There were metabolites that were consistently associated with particular imposed treatment factors in the loading plots of the PCA of H, W, and B (Supplemental Fig. 1A-C). Malic acid levels were higher in cortex from treatments where ripening was expected to be most impeded (low temperature and high $\mathrm{CO}_{2}$ ). Additionally, elevated succinic acid levels have been found in apple cortex stored in high $\mathrm{CO}_{2}$ conditions (Hulme, 1956) as well as with other cortex browning disorders (Williams and Patterson, 1964). This was confirmed in the current study where succinic acid was associated, regardless of tissue condition, with cortex stored under high $\mathrm{CO}_{2}$ conditions (T2, T4, T5, and T6).

While metabolite levels may appear to be associated with a particular treatment(s) in any given tissue condition according to PCA, PCA does not test significance of any of these differences. Additionally, the models did not explain the larger portion of the variance apparent in the data set. To control significance of individual metabolites, levels of each metabolite were compared among treatments as well as tissue types and analyzed using ANOVA followed by Fisher's LSD post hoc test (Figs. 4 and 5).
Among compounds associated with treatment in all tissue types using PCA, succinic acid, malic acid, isoleucine, valine, serine, threonine, 1-butanol, and butyl acetate were significantly different among the treatments (Fig. 4). Elevated levels of succinic acid were associated with high $\mathrm{CO}_{2}$, particularly with chilling stress coupled with high $\mathrm{CO}_{2}$ (T4-T6) (Fig. 5). No conditioning + low-temperature storage + high $\mathrm{CO}_{2}+$ DPA (T4) had the highest levels of succinic acid (Fig. 4), yet this treatment had the least disorder incidence among all the low-temperature treatments. These results have several potential implications: chilling may exacerbate high $\mathrm{CO}_{2}$ stress as higher disorder incidence in high $\mathrm{CO}_{2} /$ lowtemperature stored fruit than high $\mathrm{CO}_{2} /$ warmer temperatures stored fruit, DPA may reduce $\mathrm{CO}_{2}$ injury, as symptoms in T4 were more similar to soggy breakdown, and DPA may affect the metabolism of succinic acid. The relationship between $\mathrm{CO}_{2}, \mathrm{CO}_{2}$ injury, and other apple cortex browning injuries and succinic acid accumulation has been previously explored (Fernández-Trujillo et al., 2001; Hulme, 1956), with some suggestion of succinic acid affecting symptom development, although this new evidence indicates the relationship may not be direct given the contrasting influence of DPA treatment. Levels of acetic acid, 2-methylpropyl acetate, and ethyl 2-methylpropionate were also elevated in DPA treated fruit, suggesting additional impacts of DPA on fruit metabolism.

Higher levels of isoleucine, valine, serine, and threonine were associated with treatments with low-temperature storage and CA (T3) (Fig. 4). The accumulation of these amino acids in CA has been previously documented (Lee et al., 2012b), but evidently temperature also affects their metabolism, as temperature-conditioned + higher storage temperature (T1) with the same CA conditions as T3 did not have similar accumulations. Isoleucine and valine are potential substrates for 2-methylbutyl moiety esters (Defilippi et al., 2005; Rowan et al., 1996), but a concomitant increase of 2-methylbutanol and 2-methylbutyl acetate was not readily apparent.

Higher storage temperatures and $\mathrm{CA}$ affected fruit volatile production (Fig. 4) (T1). Butanal, butanol, butyl acetate, as well as hexanol, hexyl acetate, and hexyl butyrate were higher in fruit from T1. In 'Granny Smith', butyl and hexyl acetate levels peaked poststorage ripening from early in storage $(0-60 \mathrm{~d})$, while hexanol and butanol peaked late in storage (120 180 d) (Leisso et al., 2013).

Ethanol levels were significantly altered, most likely reflecting a combination soggy breakdown (CI) severity and ripeness (Fig. 5). Production of all three of these compounds is typically provoked by low oxygen conditions, in this case provoked by tissue injury, and ethyl acetate production is likely enhanced by available oxygen in the 

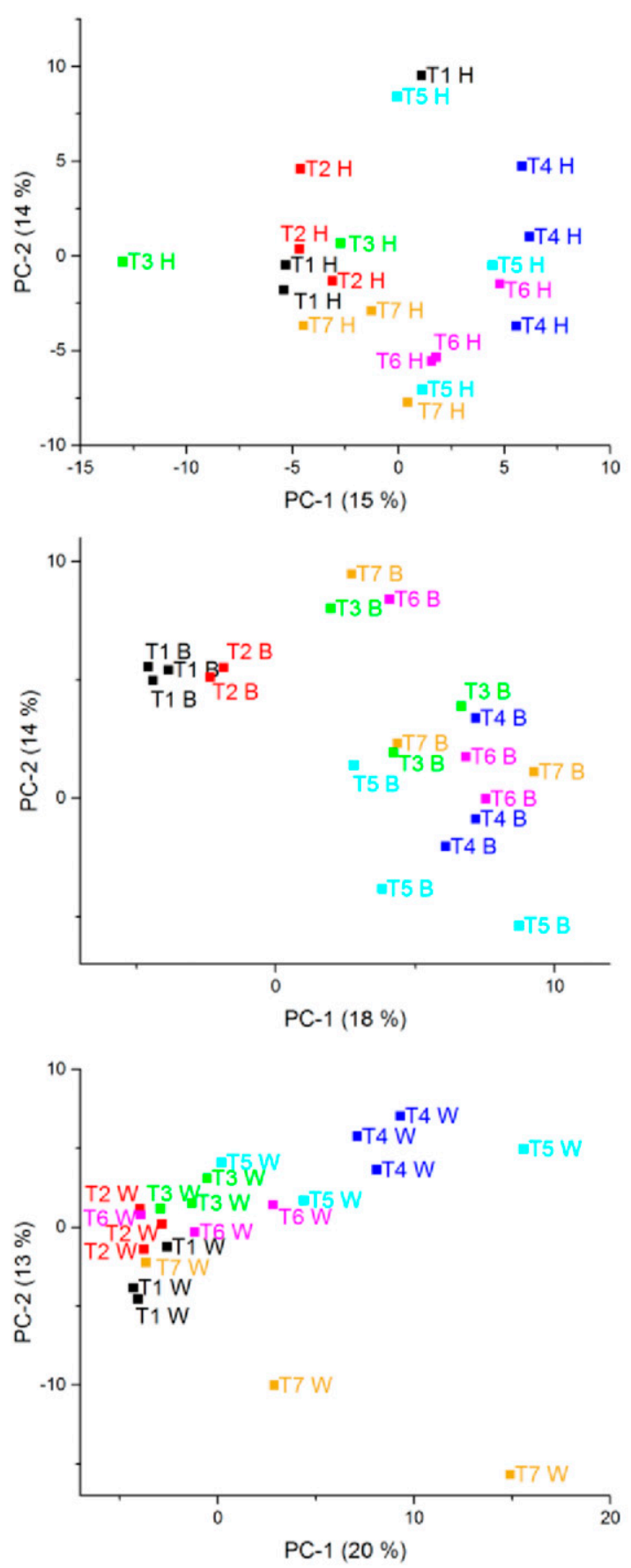

Fig. 3. Principal components analysis (PCA) scores plots from metabolic profiles of 'Honeycrisp' apple cortex from $(\mathbf{A})$ wholly healthy fruit $(\mathrm{H}),(\mathbf{B})$ white tissue next to browned tissue $(\mathrm{W})$, and $(\mathbf{C})$ browned tissue (B). Scores represent overall differences in the metabolic profile among different treatments within a specific tissue condition related to browning symptoms. Sample name and color indicates treatments $(\mathrm{T} 1=$ black, $\mathrm{T} 2=$ red, $\mathrm{T} 3=$ green, $\mathrm{T} 4=$ blue, $\mathrm{T} 5=$ cyan, $\mathrm{T} 6=$ magenta, $\mathrm{T} 7=$ ochre $)$; sample name also indicates sample tissue $(\mathrm{H}=$ wholly healthy fruit, $\mathrm{W}=$ healthy tissue in fruit affected by disorders, $\mathrm{B}=$ browned tissue in fruit affected by disorders).

surrounding tissue. To test this, ANOVA, followed by Fishers LSD post hoc test, was used to consider overall comparisons exclusive to tissue type.

Brown cortex tissue had elevated levels of ethanol, acetaldehyde, and ethyl acetate in comparison with $\mathrm{H}$ tissue although $\mathrm{W}$ and $\mathrm{H}$ tissue were not always different (Fig. 5). Levels of acetaldehyde, ethanol, and ethyl acetate higher browned cortex were also elevated tissues adjacent, healthy tissues, as in an earlier study ostensibly due to diffusion while less volatile compounds associated with damaged tissues remained in place (Leisso et al., 2015). Ethanol and acetaldehyde production are associated with both cortex affected by soggy breakdown of 'Honeycrisp' (Leisso et al., 2015; Watkins and Nock, 2012) and $\mathrm{CO}_{2}$ injury in many cultivars (Argenta et al., 2004; Fernández-Trujillo et al., 2001).
With the exception of succinic acid, volatile metabolites were more significantly affected by treatment and tissue health than primary metabolites. To determine the apparently more subtle effects of storage treatment effects on browningrelated metabolism of other compounds evaluated in cortex tissue, pathway analysis in MetPA (Xia et al., 2012) was used to summarize differential effects of treatments on compiled data from all tissues with respect to pathways involved (Fig. 6). The comparison of CA + conditioning (T1) and CA (T3) illustrates the effects of prestorage temperature conditioning on fruit metabolism (Fig. 6A). By 8 weeks, it appeared that levels of metabolites from several pathways involved in primary metabolism, were downregulated in CA with no conditioning (T3) fruit compared with CA + conditioning (T1), including pyruvate metabolism, glycolysis or gluconeogenesis, and branched-chain amino acid (valine, leucine, and isoleucine) biosynthesis. Although the rate of fruit respiration was not measured on these fruit, since T1 had a conditioning period as well as warmer storage temperatures, overall decreases of metabolite levels may be due to enhanced respiration and metabolism during storage, potentially impacting CI related pathways less than colder temperatures which was also reflected in the reduced incidence of either cortex disorder. In other words, the fruit may be more ripe following storage, but were the least damaged by physiological storage disorders.

Comparison of conditioning $+\mathrm{CA}$ with (T2) or without high $\mathrm{CO}_{2}$ (T1) may indicate pathways enhanced under high $\mathrm{CO}_{2}$ (Fig. 6B) under conditions that alleviated overall disorder incidence. The limited symptoms that developed in $\mathrm{T} 2$ were consistent with internal $\mathrm{CO}_{2}$ injury described by Smock (1977). Overall, glycolysis/gluconeogenesis, propanoate metabolism, and alanine, aspartate, and glutamate metabolism were reduced in high $\mathrm{CO}_{2}$ with conditioning and storage at the warmer temperature. Metabolite levels were different in other pathways although not consistently among glyoxylate and dicarboxylate metabolism, pyruvate metabolism, and TCA cycle.

$\mathrm{CA}+$ high $\mathrm{CO}_{2}+$ DPA (T4) and CA + high $\mathrm{CO}_{2}$ (T6) were compared with the goal of distinguishing metabolism that may be directly associated with soggy breakdown or $\mathrm{CO}_{2}$ injury at the lower temperatures as DPA used in T4 was expected to prevent $\mathrm{CO}_{2}$ injury while not impacting soft scald/ soggy breakdown development (Fig. 6C). This is based on the hypothesis that oxidative stress is more of an important cause of $\mathrm{CO}_{2}$ injury, although some evidence suggests oxidative stress is also linked to other disorders occurring in CA conditions (Burmeister and Dilley, 1995). The primary differences among these treatments were decreased amino acid metabolism in the DPA treated fruit. Other pathways were impacted, but as before, overall increases 


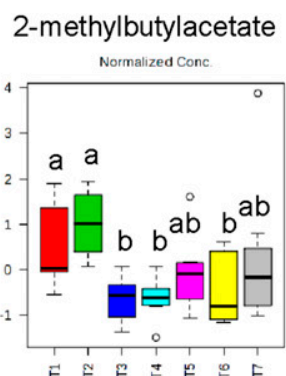

butyl acetate

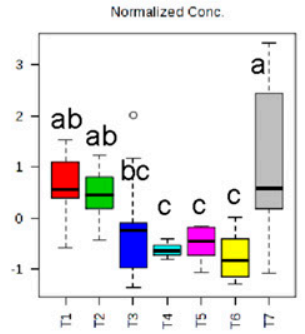

succinic acid

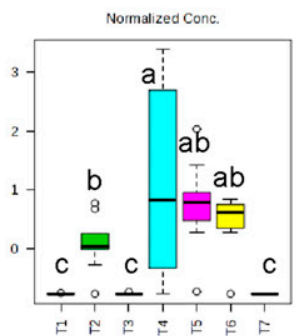

serine
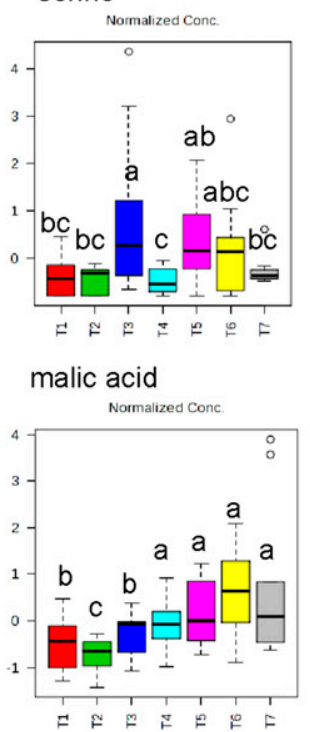

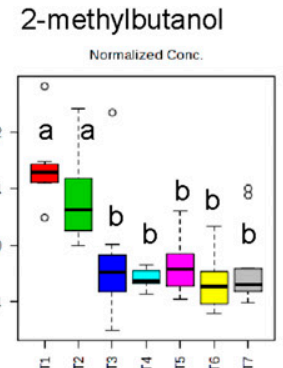

1-hexanol

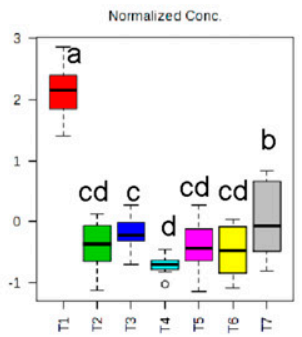

acetic acid

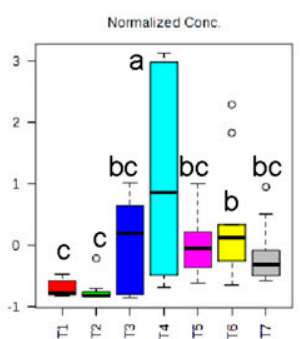

threonine

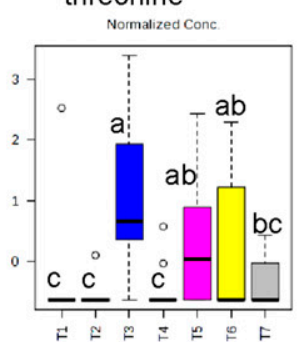

sorbitol

Normalized Con

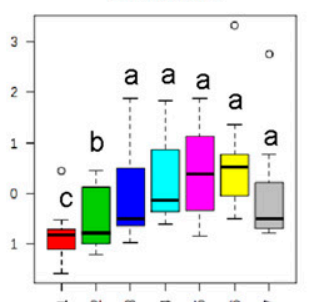

butanal

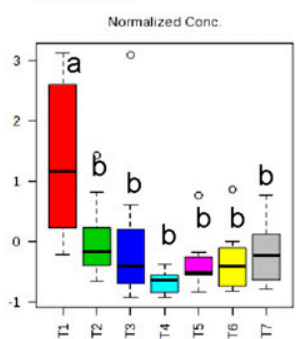

hexyl acetate

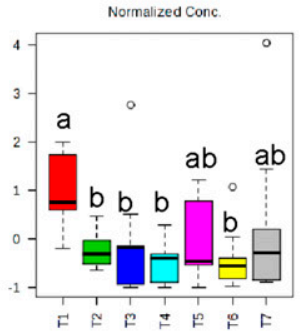

2-methylpropyl acetate

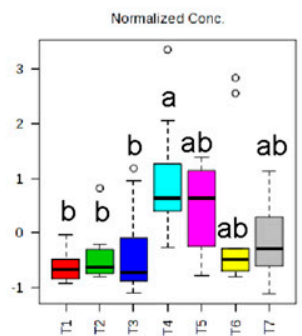

isoleucine

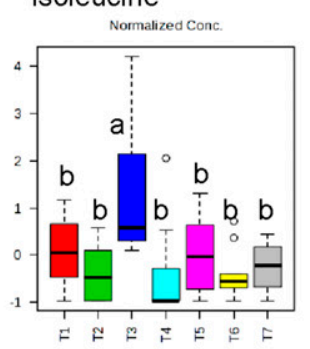

valine

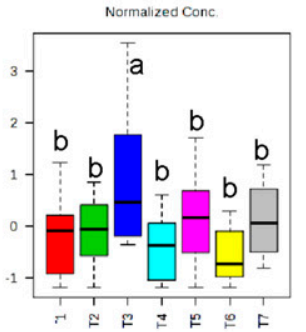

ethanol

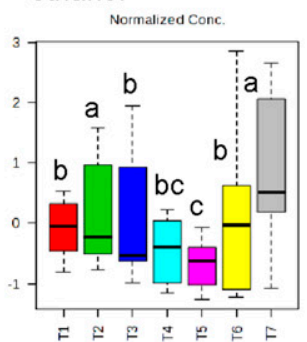

1-butanol

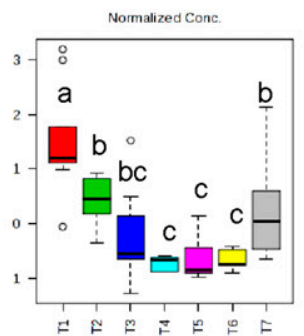

hexyl butyrate

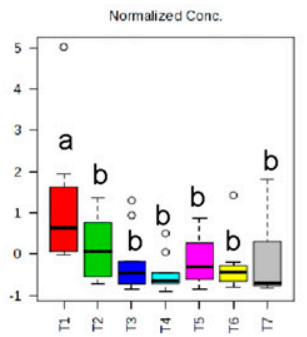

ethyl 2-methylpropionate

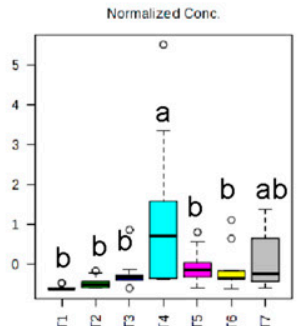

$$
\text { (n) }
$$




\section{Acetaldehyde}

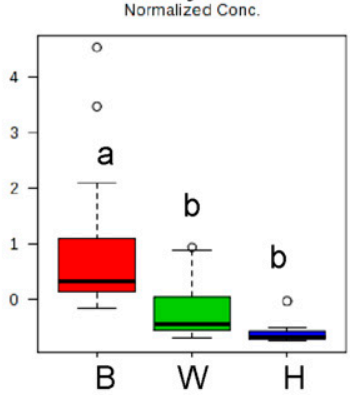

Glycerol

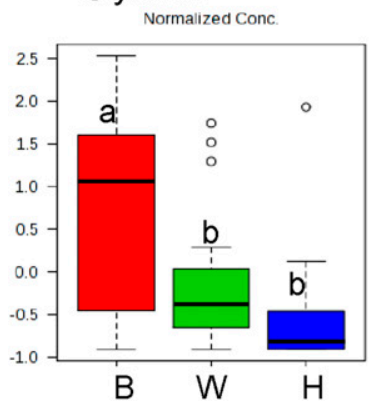

\section{Ethanol}

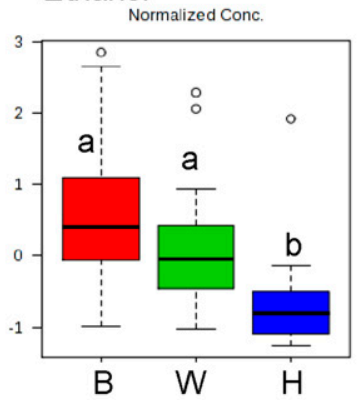

Butyl acetate

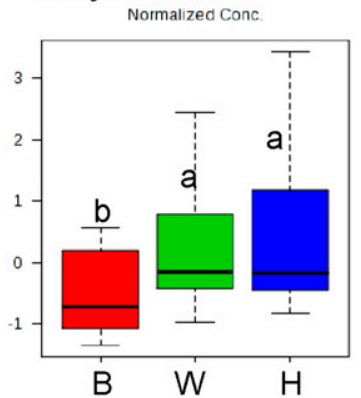

Ethyl acetate

Normalized Conc.

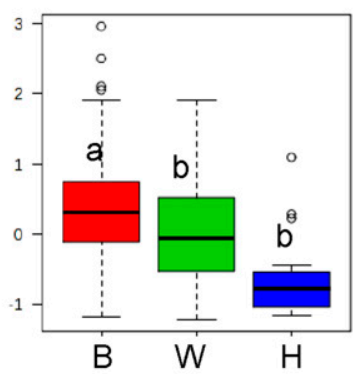

Butyl butyrate

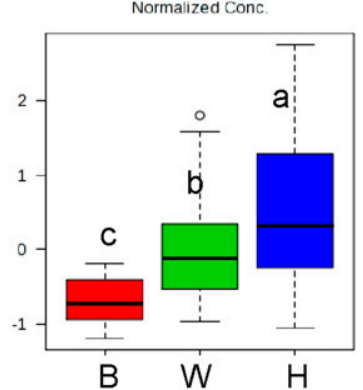

Fig. 5. Cortex metabolites differing among 'Honeycrisp' according to tissue condition with respect to browning symptoms and irrespective of treatment (where browning is present). Apples were stored under storage and crop protectant regimes that impacted postharvest disorder incidence. Boxes topped with different letters among treatments indicate significant difference. Significance was determined using a one-way analysis of variance and Fisher's least significant difference post hoc test at $P<0.05$. Boxes represent $25 \%$ to $75 \%$, bars represent 1.5 interquaternary range and horizontal lines designate the median. $\mathrm{H}=$ cortex tissue from wholly healthy fruit; $\mathrm{W}=$ healthy-appearing tissue next to browned cortex; $\mathrm{B}=$ brown cortex.

A. T1 (temp. conditioned, $1 \% \mathrm{CO}_{2} / 2 \% \mathrm{O}_{2} \mathrm{CA}$ ) compared to $\mathrm{T} 3$ (immediate $1{ }^{\circ} \mathrm{C}$ storage, $1 \% \mathrm{CO}_{2} / 2 \% \mathrm{O}_{2} \mathrm{CA}$ )

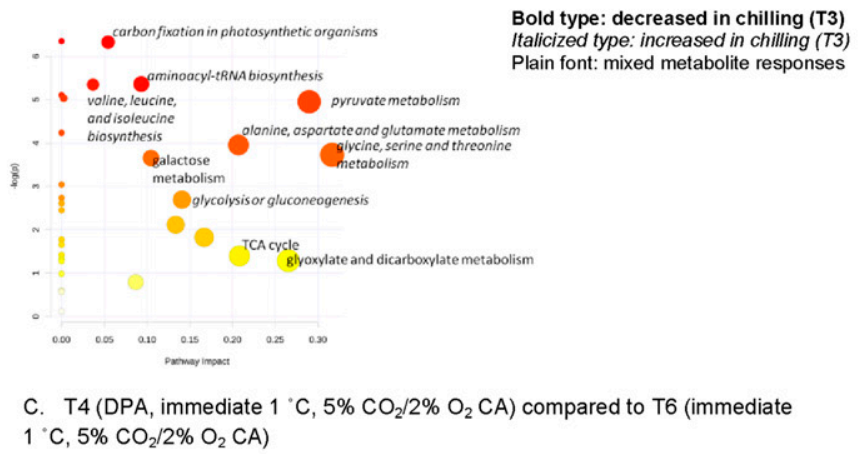

B. T1 (temp. conditioned, $1 \% \mathrm{CO}_{2} / 2 \% \mathrm{O}_{2} \mathrm{CA}$ ) compared to $\mathrm{T} 2$ (temp. conditioned, $5 \%$ $\mathrm{CO}_{2} / 2 \% \mathrm{O}_{2} \mathrm{CA}$

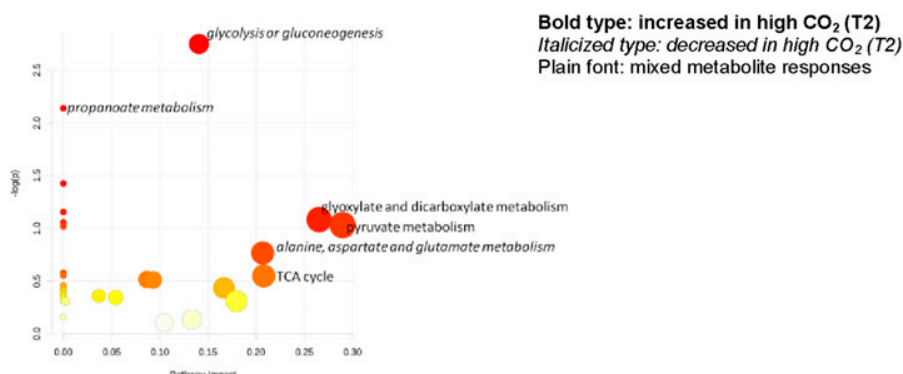

D. T6 (immediate $1^{\circ} \mathrm{C}, 5 \% \mathrm{CO}_{2} / 2 \% \mathrm{O}_{2} \mathrm{CA}$ ) compared to $\mathrm{T} 7$ (immediate $1^{\circ} \mathrm{C}$, no atmospheric modifications)

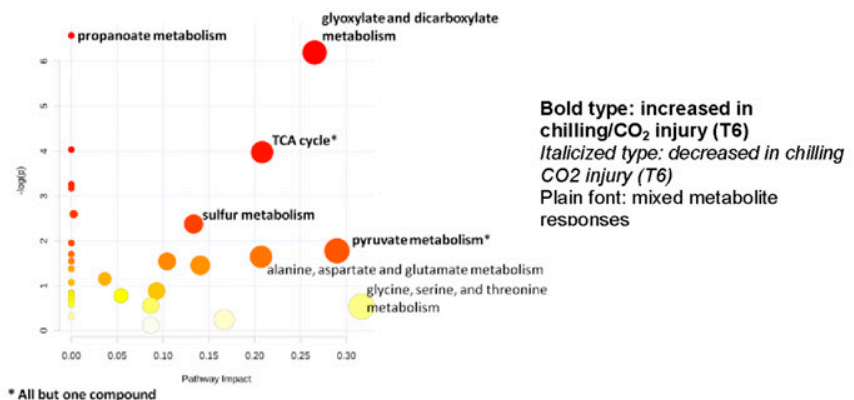

Fig. 6. Pathway analysis using MetPA (Xia et al., 2012) comparison of key combinations of postharvest treatments incorporating tissues of all conditions with respect to browning symptoms of treatments related to chilling and $\mathrm{CO}_{2}$ injury. 'Honeycrisp' apples were stored under storage and crop protectant regimes that impacted postharvest disorder incidence. Bubbles represent metabolic categories where metabolism differs between the 2 treatments indicated in each title. Altered pathways were determined using the "global test" for pathway enrichment analysis and "relative-betweenness centrality" for pathway topology analysis. Bubble color indicates level of significance based on "global test" and bubble size indicates number of compounds represented in a specific category.

used and products of fermentation were associated with symptomatic tissue and, less so, with adjacent asymptomatic tissue within the same apple. Separating these tissues allowed for the assignment of metabolic pathways possibly specific to $\mathrm{CO}_{2}$ damage including increased activity in glycolysis/gluconeogenesis, propanoate metabolism, and alanine, aspartate, and glutamate metabolism. 


\section{Literature Cited}

Argenta, L., X. Fan, and J. Mattheis. 2002. Impact of watercore on gas permeance and incidence of internal disorders in 'Fuji' apples. Postharvest Biol. Technol. 24:113-122.

Argenta, L.C., J.P. Mattheis, X. Fan, and F.L. Finger. 2004. Production of volatile compounds by Fuji apples following exposure to high $\mathrm{CO}_{2}$ or low $\mathrm{O}_{2}$. J. Agr. Food Chem. 52:5957-5963.

Barker, J. 1938. Wastage in imported fruit; its nature, extent and prevention. Spec. Rep. Dep. Scient. Ind. Res. UK.

Beaudry, R.M. and C. Contreras. 2010. A summary of 'Honeycrisp' storage recommendations across North America: What is best for Michigan? May 2015. <http://postharvest.tfrec. wsu.edu/rep2010a.pdf $>$.

Burmeister, D.M. and D.R. Dilley. 1995. A 'scaldlike' controlled atmosphere storage disorder of Empire apples-a chilling injury induced by $\mathrm{CO}_{2}$. Postharvest Biol. Technol. 6:1-7.

Contreras, C., N. Alsmairat, and R. Beaudry. 2014. Prestorage conditioning and diphenylamine improve resistance to controlled-atmosphererelated injury in 'Honeycrisp' apples. HortScience 49:76-81.

Chiu, G.Z., B.J. Shelp, S.R. Bowley, J.R. DeEll, and G.G. Bozzo. 2015. Controlled atmosphererelated injury in 'Honeycrisp' apples is associated with $\gamma$-aminobutyrate accumulation. Can. J. Plant Sci. 95:879-886.

de Castro, E., D.M. Barrett, J. Jobling, and E.J. Mitcham. 2008. Biochemical factors associated with a $\mathrm{CO}_{2}$-induced flesh browning disorder of Pink Lady apples. Postharvest Biol. Technol. 48:182-191.

Defilippi, B.G., A.M. Dandekar, and A.A. Kader. 2005. Relationship of ethylene biosynthesis to volatile production, related enzymes, and precursor availability in apple peel and flesh tissues. J. Agr. Food Chem. 53:3133-3141.

DeLong, J.M., R.K. Prange, and P.A. Harrison. 2004. The influence of pre-storage delayed cooling on quality and disorder incidence in 'Honeycrisp' apple fruit. Postharvest Biol. Technol. 33:175-180.

DeLong, J.M., R.K. Prange, P.A. Harrison, C.G. Embree, D.S. Nichols, and A.H. Wright. 2006. The influence of crop-load, delayed cooling and storage atmosphere on post-storage quality of 'Honeycrisp' 'TM apples. J. Hort. Sci. Biotechnol. 81:391-396.

Felicetti, E., J.P. Mattheis, Y. Zhu, and J.K. Fellman. 2011. Dynamics of ascorbic acid in 'Braeburn' and 'Gala' apples during on-tree development and storage in atmospheres conducive to internal browning development. Postharvest Biol. Technol. 61:95-102.

Fernández-Trujillo, J.P., J.F. Nock, and C.B. Watkins. 2001. Superficial scald, carbon dioxide injury, and changes of fermentation products and organic acids in 'Cortland' and 'Law Rome' apples after high carbon dioxide stress treatment. J. Amer. Soc. Hort. Sci. 126:235-241.
Fiehn, O. 2002. Metabolomics - the link between genotypes and phenotypes. Plant Mol. Biol. 48:155-171.

Hanrahan, I. and J.R. McFerson. 2010. Extending the Honeycrisp marketing season in Washington State. HortScience 45:S168-S169.

Ho, Q.T., P. Verboven, B.E. Verlinden, A. Schenk, M.A. Delele, H. Rolletschek, J. Vercammen, and B.M. Nicolai. 2010. Genotype effects on internal gas gradients in apple fruit. J. Expt. Bot. 61:2745-2755.

Hulme, A.C. 1956. Carbon dioxide injury and the presence of succinic acid in apples. Nature 178:218-219.

Kanehisa, M. and S. Goto. 2000. KEGG: Kyoto encyclopedia of genes and genomes. Nucleic Acids Res. 28:27-30

Lee, J., J.P. Mattheis, and D.R. Rudell. 2012a. Antioxidant treatment alters metabolism associated with internal browning in 'Braeburn' apples during controlled atmosphere storage. Postharvest Biol. Technol. 68:32-42.

Lee, J., D. Rudell, P. Davies, and C.B. Watkins. 2012b. Metabolic changes in 1-methylcyclopropene (1-MCP)-treated 'Empire' apple fruit during storage. Metabolomics 8:742-753.

Leisso, R., D. Buchanan, J. Lee, J. Mattheis, and D. Rudell. 2013. Cell wall, cell membrane, and volatile metabolism are altered by antioxidant treatment, temperature shifts, and peel necrosis during apple fruit storage. J. Agr. Food Chem. 61:1373-1387.

Leisso, R.S., D.A. Buchanan, J. Lee, J.P. Mattheis, C. Sater, I. Hanrahan, C.B. Watkins, N. Gapper, J.W. Johnston, R.J. Schaffer, M.L.A.T.M. Hertog, B.M. Nicolai, and D.R. Rudell. 2015. Chillingrelated cell damage of apple (Malus $\times$ domestica Borkh.) fruit cortical tissue impacts antioxidant lipid and phenolic metabolism. Physiol. Plant. 153:204-220.

Mattheis, J.P., D.A. Buchanan, and J.K. Fellman 1998. Volatile compounds emitted by 'Gala' apples following dynamic atmosphere storage. J. Amer. Soc. Hort. Sci. 123:426-432.

Mattheis, J.P. and D.R. Rudell. 2008. Diphenylamine metabolism in 'Braeburn' apples stored under conditions conducive to the development of internal browning. J. Agr. Food Chem. 56:3381-3385.

Meheriuk, M. and O.L. Lau. 1984. Flesh browning in CA-stored Red Delicious apples. Proc. Wash. St. Hort. Assoc. 147-148.

Patti, G.J., O. Yanes, and G. Siuzdak. 2012. Innovation: Metabolomics: The apogee of the omics trilogy. Nat. Rev. Mol. Cell Biol. 13:263-269.

Plagge, H.H. and T.J. Maney. 1928. Soggy breakdown of apples and its control by storage temperature. Iowa Agr. Exp. Sta. Res. Bull. 115:57-118.

Prange, R.K. and J.M. DeLong. 2006. Controlledatmosphere related disorders of fruits and vegetables. Stewart Postharvest Rev. 2:1-10.

Rowan, D.D., H.P. Lane, J.M. Allen, S. Fielder, and M.B. Hunt. 1996. Biosynthesis of 2-methylbutyl, 2-methyl-2-butenyl, and 2-methylbutanoate esters in Red Delicious and Granny Smith apples using deuterium-labeled substrates. J. Agr. Food Chem. 44:3276-3285.

Rudell, D.R. and J.P. Mattheis. 2009. Superficial scald development and related metabolism is modified by postharvest light irradiation. Postharvest Biol. Technol. 51:174-182.

Rudell, D.R., J.P. Mattheis, and M.L.A.T.M. Hertog. 2009. Metabolomic change precedes apple superficial scald symptoms. J. Agr. Food Chem. 57:8459-8466.

Rudell, D.R., D.A. Buchanan, R.S. Leisso, B.D. Whitaker, J.P. Mattheis, Y. Zhu, and V. Varanasi. 2011. Ripening, storage temperature, ethylene action, and oxidative stress alter apple peel phyotosterol metabolism. Phytochemistry 72:1328-1340.

Smock, R.M. 1977. Nomenclature for internal storage disorders of apples. HortScience 12:306-308.

Snowdon, A.L. 1990. A color atlas of post-harvest diseases and disorders of fruits and vegetables. CRC Press, Boca Raton, FL.

Tong, C.B.S., D.S. Bedford, J.J. Luby, F.M. Propsom, R.M. Beaudry, J.P. Mattheis, C.B. Watkins, and S.A. Weis. 2003. Location and temperature effects on soft scald in 'Honeycrisp' apples. HortScience 38:1153-1155.

Watkins, C.B. and J. Nock. 2012. Controlledatmosphere storage of 'Honeycrisp' apples. HortScience 47:886-892.

Watkins, C.B., J. Nock, S.A. Weis, S.S. Jayanty, and R.M. Beaudry. 2004. Storage temperature, diphenylamine, and pre-storage delay effects on soft scald, soggy breakdown, and bitter pit of 'Honeycrisp' apples. Postharvest Biol. Technol. 32:213-221.

Watkins, C.B., M. Erkan, J.E. Nock, K.A. Lungerman, R.M. Beaudry, and R.E. Moran. 2005. Harvest date effects on maturity, quality, and storage disorders of 'Honeycrisp' apples. HortScience 40:164-169.

Williams, M.W. and M.E. Patterson. 1964. Storage effects on fruits, nonvolatile organic acids and core breakdown of Bartlett pears. J. Agr. Food Chem. 12:80-83.

Wills, R.B.H., G. Hopkirk, and K.J. Scott. 1981 Reduction of soft scald in apples with antioxidants. J. Amer. Soc. Hort. Sci. 106:569-571.

Wills, R.B.H. and K.J. Scott. 1982. Use of dips containing diphenylamine and edible oils to reduce soft scald of apples. HortScience 17:964-965.

Xia, J., R. Mandal, I. Sinelnikov, D. Broadhurst, and D.S. Wishart. 2012. MetaboAnalyst 2.0a comprehensive server for metabolomic data analysis. Nucleic Acids Res. 1.

Xia, J., N. Psychogios, N. Young, and D.S. Wishart. 2009. MetaboAnalyst: A web server for metabolomic data analysis and interpretation. Nucleic Acids Res. 37:W652-W660.

Zhang, Y., P. Li, and L. Cheng. 2010. Developmental changes of carbohydrates, organic acids, amino acids, and phenolic compounds in 'Honeycrisp' apple flesh. Food Chem. 123:1013-1018 

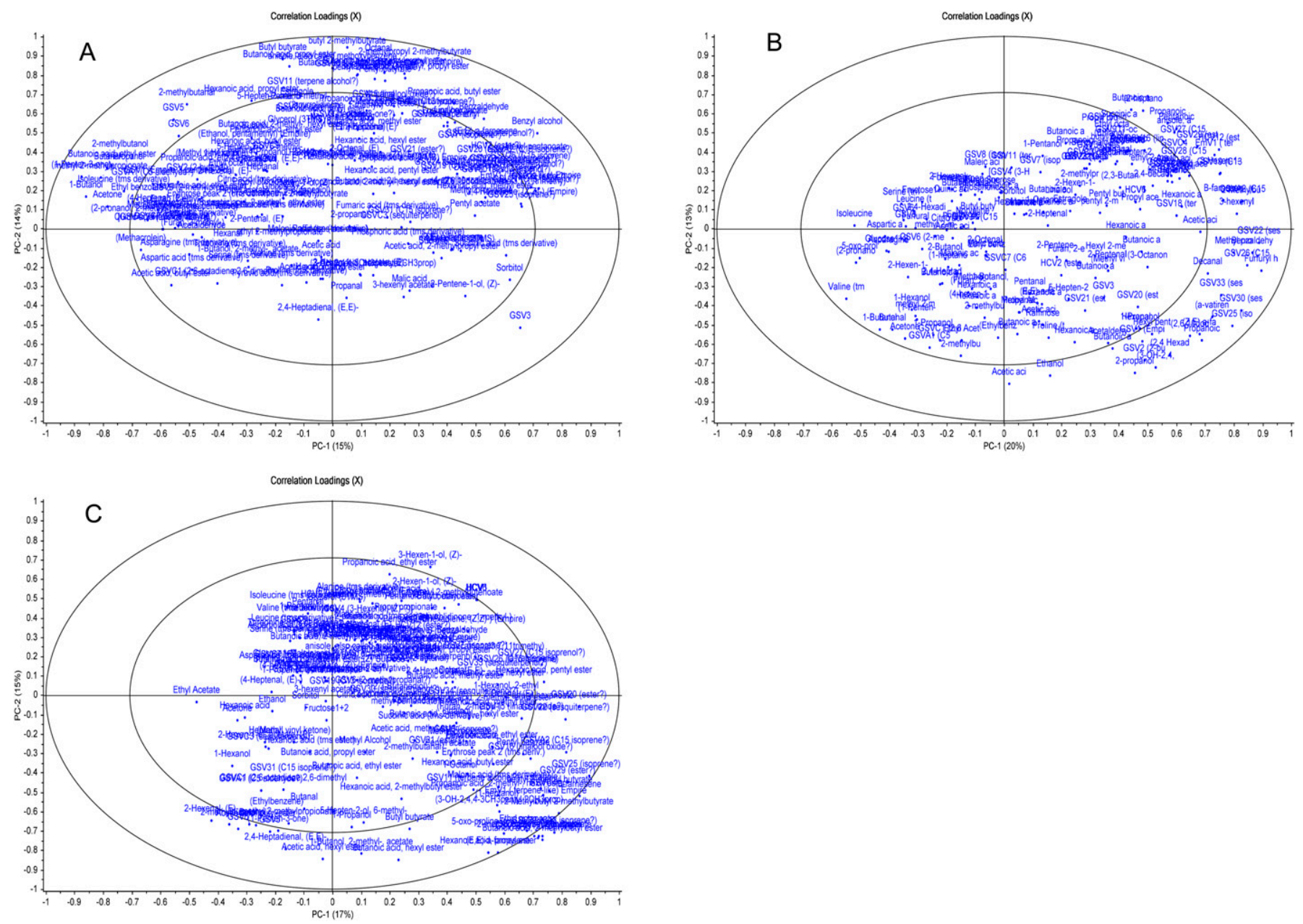

Supplemental Fig. 1. Principal components analysis (PCA) correlation loading plots from metabolic profiles of 'Honeycrisp' apple cortex from (A) wholly healthy fruit, (B) white tissue next to browned tissue, and (C) browned tissue. Position of metabolite labels with respect to scores for each observation (Fig. 3A-C) indicates association among metabolites and that observation. 